\title{
PENERAPAN METODE RATIONAL UNIFIED PROCESS (RUP) DALAM PENGEMBANGAN SISTEM INFORMASI MEDICAL CHECK UP PADA CITRA MEDICAL CENTRE
}

\author{
(The Application of RationalUnifiedProcess (RUP) in Development of a Medical \\ CheckUpInformation System at Citra Medical Centre)
}

\author{
RirinPerwitasari", RoyanaAfwani, Sri Endang Anjarwani \\ Program Studi Teknik Informatika, Fakultas Teknik, Universitas Mataram \\ JI. Majapahit 62, Mataram, Lombok NTB, INDONESIA \\ Email: ririnperwita2104@gmail.com,[royana,endang]@unram.ac.id
}

\begin{abstract}
The Rational Unified Process (RUP) method is an iterative and incremental software development methodwithfourstage. The firstisinceptionstage to defining the system requirements and use casediagram, then designed previously issued by the user for conformity. Second stage is elaborationstageto improvementrequirementandusecase diagram, anddesigning another diagram design till interface design. Test elaborationby validating features with user. Constructionstage direct implementation of the design that has been made inbeforestageand carried out testing usingblack box testing. The last is transitionstagewill be tested at the end of the system that has been built. Testing is done usingquestionnaire conducted by 2 people from the clinic and 30 people from the community with the results obtainedamounted to $86.12 \%$ (very feasible) so the RUP method is a good method to be used in system development.
\end{abstract}

Keywords:RationalUnifiedProcess, RUP, Information System, Medical CheckUp.

*Penulis Korespondensi

\section{Pendahuluan}

Metode RUP merupakan metode pembangunan perangkat lunak yang iterative dan incremental serta berfokus pada arsitektur. Metode RUP dapat menangani risiko yang berhubungan dengan pengembangan kebutuhan sistem berdasarkan perubahan yang diinginkan oleh klien. Untuk mengurangi risiko tersebut dilakukan dengan pengujian pada setiap akhir tahapan RUP, sehingga akan mudah melakukan perubahan sebelum mencapai tahap akhir. Metode RUP juga mengutamakan kepuasan pengguna sehingga lebih sering melakukan interaksi dengan pengguna[1].

Metode RUP digunakan dalam pengembangan sistem informasi medicalcheckup pada Citra Medical Centre mulai dari proses pendaftaran pasien, pengolahan hasil pemeriksaan dan penyerahan hasil pemeriksaan ke pasien. Medical checkup merupakan pemeriksaan kesehatan secara menyeluruh mulai dari pemeriksaan fisik serta pemeriksaan laboratorium[2]. Salah satu tempat pemeriksaan kesehatan yang telah ditetapkan oleh Dirjen Bina Upaya Kesehatan Badan Nasional Penempatan dan Perlindungan Tenaga Kerja
Indonesia (BNP2TKI) adalah Citra Medical Centre yang terletak di kawasan Lombok Timur[3]. Dalam pelaksanaannya, Citra Medical Centre telah menggunakan sebuah aplikasi berbasis desktopyang digunakan sebagai pengelolaan data pasien. Namun adanya aplikasi desktop tersebut belum memenuhi kebutuhan pegawai karena pengaksesannya terbatas hanya pada jam kantor. Oleh karena itu, dilakukan pengembangan aplikasi berbasis web dengan menggunakan metode RUP untuk melakukan pengelolaan data pasien dari mana saja dan kapan saja.

Metode RUP digunakan dalam pengembangan sistem informasi medical checkup untuk mengantisipasi pendefinisian kebutuhan sistem yang tidak terlalu detail pada tahap awal. Dengan menggunakan metode RUP, hal tersebut dapat diatasi dengan adanya pengujian yang dilakukan oleh pengguna pada setiap akhir tahapan RUP untuk mengetahui kebutuhan sistem dan kesesuaian proses pengembangan sistem pada setiap tahapan. Tujuan melibatkan pengguna dalam setiap proses dalam RUP adalah untuk menghasilkan sistem yang sesuai dengan harapan pengguna. 


\section{TINJAUAN PUSTAKA DAN DASAR TEORI}

\subsection{Tinjauan Pustaka}

Penelitian tentang sistem informasi pendistribusian suku cadang industri pada CV.Oilfindo menggunakan metode RUP untuk membantu karyawan dalam memproses pesanan dan pembuatan laporan sehingga pekerjaan karyawan menjadi efektif dan efisien[4]. Perbedaannya dengan penelitian yang akan dilakukan adalah fokus penelitiannya pada sistem yang dibangun, sedangkan penelitian yang akan dilakukan berfokus pada metodenya yaitu menggunakan RUP dalam pengembangan sistemnya.

Penelitian tentang analisis dan pengembangan sistem ujian akhir semester berbasis berbasis web di SMK Negeri 1 Malang bertujuan untuk penyelenggaraan ujian akhir semester yang digunakan oleh guru dan siswa [5]. Perbedaannya dengan penelitian ini adalah jenis penelitiannya, di mana peneliti sebelumnya terletak pada analisis hasil pengembangan sistem, sedangkan pada penelitian yang penulis lakukan yaitu penerapan metode dalam pengembangan sistem. Persamaan antara kedua penelitian adalah penggunaan metode RUP dalam pengembangan sistem yang memungkinkan perubahan selama proses pengembangan.

Penelitian tentang penerapan metode SDLC RUP (Rational Unified Process) dalam pembuatan sistem informasi E-kos berbasis web pada kota malang dibangun untuk memudahkan mahasiswa dalam mencari tempat kos dan juga memudahkan pemilik kos untuk mengiklankan kosnya[6]. Perbedaannya dengan penelitian yang akan dilakukan adalah jenis penelitian yang dilakukan. Penelitian sebelumnya membangun sistem informasi untuk memudahkan pencarian kos, sedangkan penelitian yang akan dilakukan adalah pengembangan sistem informasi medical checkup pada klinik. Persamaan penelitian yang akan dilakukan dengan penelitian sebelumnya yaitu menggunakan metode Rational Unified Process (RUP) dalam pengembangan sistem, di mana keempat tahap RUP akan membantu peneliti untuk merancang sistem informasi yang akan dibangun.

Penelitian yang berjudul a comparison between two software engineering process, RUP and waterfall models pengembangan sistem informasi data medicalcheckup bertujuan untuk membandingkan antara dua model pengembangan perangkat lunak yaitu RUP dan waterfall untuk menunjukkan fitur dan kekurangan masing-masing model [7]. Kelebihan dari RUP adalah fleksibel jika user ingin melakukan perubahan pada setiap tahapan pengembangan, sedangkan untuk waterfall tidak dapat terlalu banyak melakukan revisi atau perubahan. Kelemahan RUP adalah prosesnya yang bisa jadi terlalu banyak karena dimungkinkan adanya perubahan, sedangkan waterfall menggunakan tahapan pasti sehingga mudah digunakan.

Pada penelitian a comparison between three SDLC models waterfall model, spiral model, and incremental / iterative model bertujuan untuk membandingkan ketiga model SDLC tersebut[8]. Perbedaan ketiga model dari segi flexibility, model waterfall merupakan model yang paling tidak fleksibel, model spiral agak fleksibel, dan model RUP yang paling fleksibel. Dari segi jaminan keberhasilan, model waterfall kurang dijamin keberhasilannya, sedangkan model spiral dan RUP jaminan keberhasilannya tinggi. Dari segi pengujian, model waterfall lambat dalam melakukan pengujian, sedangkan untuk model spiral dan RUP cepat dalam melakukan pengujian bahkan dilakukan di akhir setiap iterasi untuk model RUP[9].

\subsection{Dasar Teori}

Untuk mendasari dari penelitian ini digunakan beberapa dasar teori adalah sebagai berikut.

\subsubsection{Metode Rational Unified Process (RUP)}

Seperti telah diuraikan sebelumnya bahwa metode perangkat lunak yang dikembangan dilakukan secara interative dan incremental yang menekankan pada arsitektur. Untuk menggambarkan fase yang digunakan dalam metode ini seperti terlihat pada Gambar 1.

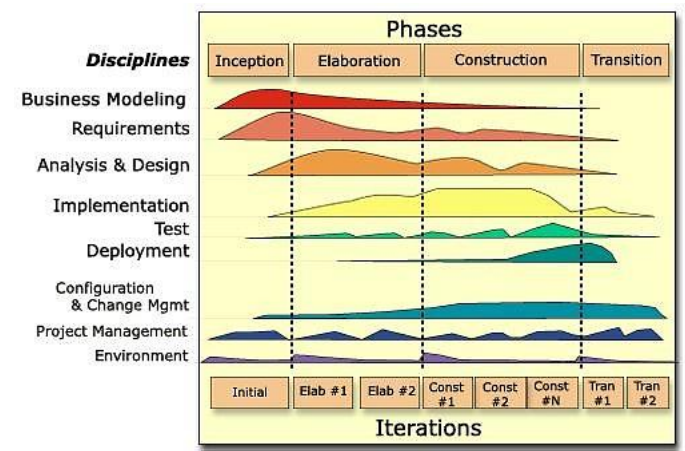

Gambar 1. Arsitektur metode RUP

RUP memiliki empat tahap yaitu inception, elaboration, contruction, dan transition[4]. Berikut penjelasan mengenai empat tahap pengembangan RUP.

a. Inception

Tahap ini lebih pada memodelkan proses bisnis yang dibutuhkan (business modeling), mendefinisikan kebutuhan akan sistem yang 
akan dibuat (requirement) serta analisis dan desain.

b. Elaboration

Tahap ini lebih pada analisis dan desain sistem serta implementasi sistem yang fokus pada purwarupa sistem (prototype).

c. Construction

Tahap ini lebih pada implementasi dan pengujian sistem yang fokus pada implementasi perangkat lunak pada kode program.

d. Transition

Tahap ini lebih pada deploymentatau instalasi sistem agar dapat dimengerti oleh user.

\subsubsection{ISO 25010}

ISO 25010 adalah standar kualitas perangkat lunak yang baru, sebagai pengganti ISO 9126. Pada penelitian ini diambil 2 karakteristik yaitu functional suitability, dan usability adalah sebagai berikut [5]:

a. Functional Suitability

Pengujian functional suitability menggunakan metode blackbox testing. Hasil pengujiannya dihitung dengan rumus:

$$
X=\mathrm{P} / \mathrm{I}
$$

Keterangan:

$\mathrm{P}=$ Jumlah fitur yang dirancang

I = Jumlah fitur yang berhasil

diimplementasikan

Dalam pengujian, produk dikatakan baik dalam functional suitability jika nilai X mendekati 1 .

b. Functional Usability

Pada pengujian usability, digunakan kuesioner dengan rumus sebagai berikut:

Berikut rumus perhitungan skor pengujian usability:

Skortotal $=(U S S \times 5)+(U S \times 4)+(U N \times 3)+$

$$
(J T S \times 2)+(J S T S \times 1)
$$

Keterangan:

JSS = jumlah responden menjawab Sangat Setuju

JS = jumlah responden menjawab Setuju

$\mathrm{JN}=$ jumlah responden menjawab Netral

JTS = jumlah responden menjawab Tidak Setuju

JSTS = jumlah responden menjawab Sangat Tidak Setuju

Kemudian mencari persentase skor untuk mendapatkan kriteria interpretasi hasil pengujian usability dengan rumus:
Pskor $=$ Skor total i $\times r \times 5 \times 100 \%$

Keterangan:

Skor total = skor total hasil jawaban responden $\mathrm{i}=$ jumlah pertanyaan

$r=$ jumlah responden

\section{MetodePenelitian}

Dalam pengembangan sistem menggunakan beberapa tahapan yang mengikuti metode RUP seperti yang terlihat pada Gambar 2.

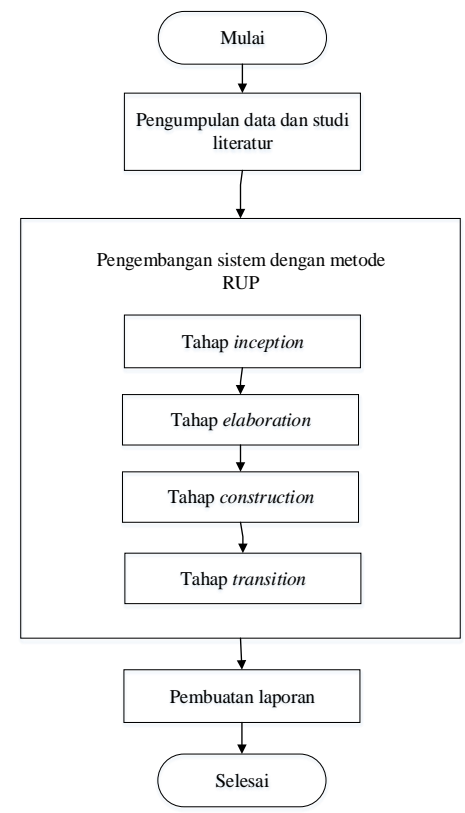

Gambar 2. Tahapan pengembangan sistem pada penelitian.

Penjelasan dari tahapan pengembangan pada Gambar 2 adalah sebagai berikut.

\subsection{Pengumpulan Data dan Studi Literatur}

Pengumpulan data dilaksanakan dengan dua cara yaitu observasi dan wawancara.

\subsubsection{Observasi}

Pada tahap ini, penulis mengamati secara langsung bagaimana proses pendaftaran medicalcheckup, pengelolaan data pasien, dan pembuatan hasil pemeriksaan oleh pegawai Citra Medical Centre.

\subsubsection{Wawancara}

Berdasarkan wawancara diketahui masalah yang ada yaitu penggunaan server lokal sehingga pengelolaan data pasien hanya bisa dikerjakan pada jam kantor. Sehingga penulis menawarkan untuk melaksanakan penelitian pengembangan sebuah 
sistem informasi yang dapat membantu terkait pendaftaran medical checkup secara online dan pengelolaan data yang dapat dikerjakan di mana saja dan kapan saja.

\subsubsection{Studi literatur}

Penulis melakukan studi literatur terhadap artikel, jurnal, dan skripsi yang sesuai dengan permasalahan yang ada sebagai bahan rujukan dan memperkuat argumentasi dari informasi diperoleh.

\subsection{Pengembangan Sistem dengan Metode RUP}

Pada pengembangan sistem dengan metode RUP, tahapan yang digunakan adalah tahap inception, elaboration, construction, dan transition.

\subsubsection{Tahap Inception}

Pada tahap inception terdapat beberapa proses RUP yang dilakukan diantaranya membuat business modelling, requirements, analysis and design, $\mathrm{d}$ antest.

a. Business modelling

Business modelling yang digunakan adalah Business modelling canvas(BMC) seperti Gambar 3.

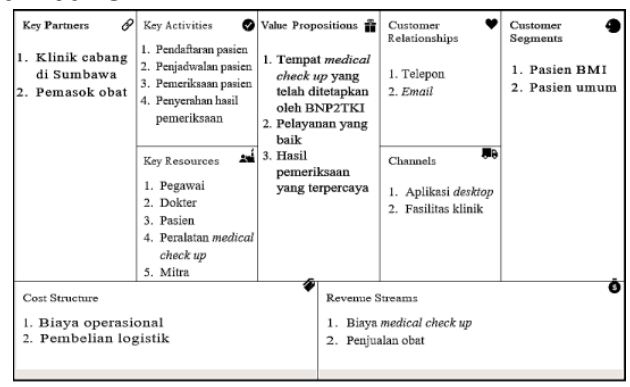

Gambar 3. Perancangan business modelling canvas penelitian.

Dari BMC pada Gambar 3 yang dibutuhkan pada penelitian adalah Key Activities, CustomerRelationship,

CustomerSegmentsdanChannels.

b. Requirements

Kebutuhan fungsional sistem seperti yang terlihat pada Tabel I[10].

TABEL I. KEBUTUHANFUNGSIONALSISTEM

\begin{tabular}{|c|l|c|}
\hline $\begin{array}{c}\mathrm{N} \\
\mathrm{O}\end{array}$ & \multicolumn{1}{|c|}{ Kebutuhanfungsional } & Aktor \\
\hline 1 & $\begin{array}{l}\text { Melakukanpendaftaranuntukmenjad } \\
\text { i member }\end{array}$ & Pasien \\
\hline 2 & $\begin{array}{l}\text { Melakukanpendaftaran medical } \\
\text { check up }\end{array}$ & Pasien \\
\hline 3 & $\begin{array}{l}\text { Melihatjadwalpemeriksaanpribadi } \\
\text { Pasien }\end{array}$ & Pasien \\
\hline 4 & $\begin{array}{l}\text { Mengubah data pribadi } \\
\text { Mengelola data pasien (melihat, } \\
\text { menambahkan, mengubah, } \\
\text { danmenghapus) }\end{array}$ & $\begin{array}{c}\text { Pegawa } \\
\mathrm{i}\end{array}$ \\
\hline
\end{tabular}

\begin{tabular}{|c|l|c|}
\hline 6 & $\begin{array}{l}\text { Mengelolahasilpemeriksaan } \\
\text { (melihat, menambahkan, } \\
\text { mengubah, } \\
\text { danmenghapus) }\end{array}$ & $\begin{array}{c}\text { Pegawa } \\
\mathrm{i}\end{array}$ \\
\hline 7 & $\begin{array}{l}\text { Mengelolariwayatpasien } \\
\text { (melihatdanmenghapus) }\end{array}$ & $\begin{array}{c}\text { Pegawa } \\
\mathrm{i}\end{array}$ \\
\hline
\end{tabular}

c. Analysis and design

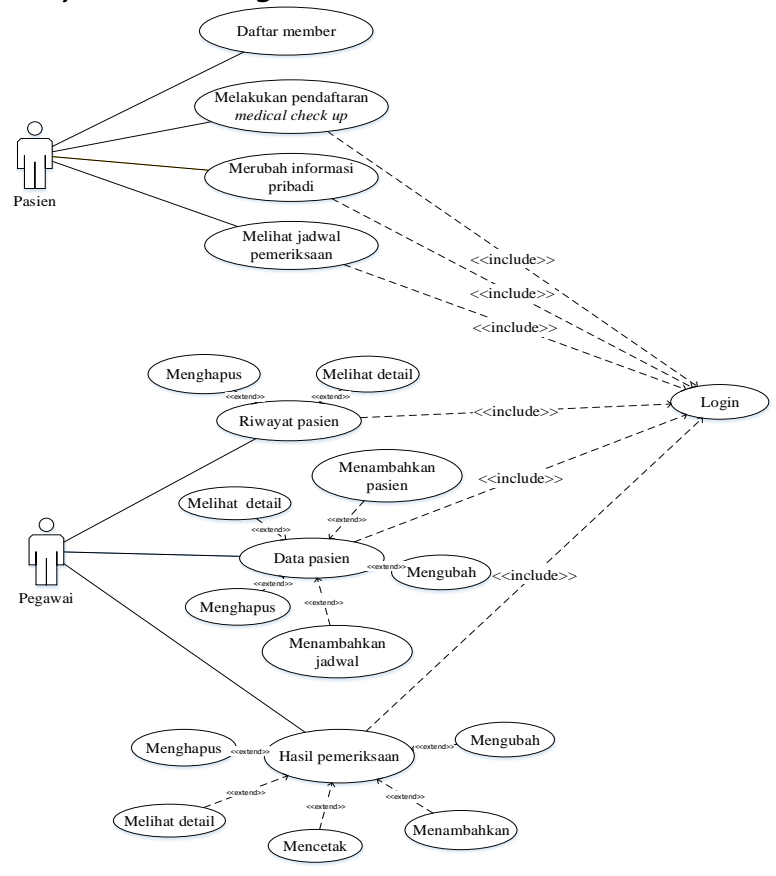

Gambar 4.Usecase diagram sistem.

Analisis pada tahap inception dijelaskan dengan menggunakan usecase diagram seperti pada Gambar 4. Terdapat dua aktor yang berperan yaitu pasien dan pegawai. Masing-masing aktor tersebut memiliki hak akses yang berbeda. Pasien memiliki 4 hak akses sedangkan pegawai memiliki 3 hak akses.

d. Test

Pada tahap ini, pengujian bertujuan untuk memvalidasi kebutuhan sistem dan usecase yang telah dirancang. Pengujian melibatkan 2 orang penguji yang berperan sebagai pengguna sistem yaitu pegawai dan pimpinan klinik. Pengujian dilakukan dengan mencocokkan usecase berdasarkan kebutuhan fungsional sistem untuk pasien dan pegawai. Proses validasi dimulai dengan peneliti memberikan tabel isian yang kemudian diisi dan di validasi oleh masing-masing penguji pada klinik. Hasil validasi dapat dilihat pada Tabel II.

TABEL II. VALIDASIKEBUTUHANSISTEMDAN USE CASE

\begin{tabular}{|l|l|l}
$\mathrm{N}$ & Kebutuhanfungsionalsistem & Use case
\end{tabular} 


\begin{tabular}{|c|l|c|c|}
\hline o & & $\begin{array}{l}\text { Pasie } \\
\text { n }\end{array}$ & $\begin{array}{l}\text { Pegaw } \\
\text { ai }\end{array}$ \\
\hline 1 & Daftarmenjadi member & $\checkmark$ & \\
\hline 2 & Daftar Medical check up & $\checkmark$ & \\
\hline 3 & $\begin{array}{l}\text { Melihatjadwalpemeriksaanpr } \\
\text { ibadi }\end{array}$ & $\checkmark$ & \\
\hline 4 & Mengubah data pribadi & $\checkmark$ & \\
\hline 5 & $\begin{array}{l}\text { Mengelola data pasien } \\
\text { (melihat, } \\
\text { menambahkanpasien, } \\
\text { mengubah, } \\
\text { menambahkanjadwal, } \\
\text { danmenghapus }\end{array}$ & $\begin{array}{l}\text { Mengelolariwayatpasien } \\
\text { (melihatdanmenghapus) }\end{array}$ & $\begin{array}{l}\text { Mengelolahasilpemeriksaan } \\
\text { (melihat, menambahkan, } \\
\text { mengubah, mencetak, } \\
\text { danmenghapus) }\end{array}$ \\
\hline 6 & $\checkmark$ \\
\hline
\end{tabular}

Dari validasi yang dilakukan diperoleh hasil bahwa kebutuhan dan usecase sistem yang dirancang sesuai dengan kebutuhan pengguna. Dengan demikian proses dapat dilanjutkan menuju tahap selanjutnya yaitu tahap elaboration.

\subsubsection{Tahap Elaboration}

Tahap elaboration merupakan tahap setelah inception.Pada tahap ini terdapat proses RUP yaitu requirements, analysisanddesign, implementation, dan test.

a. Requirements

Terdapat penambahan kebutuhan fungsional sistem dari tahap sebelumnya pada Tabel Iyaitu pasien dapat melihat riwayat pemeriksaan pribadinya.

b. Analysis and design

Pada analysisanddesign tahap elaboration terdapat usecase diagram, activity diagram, class diagram, sequencediagram dan ERD.

1. Usecase diagram

Usecase diagramyang telah dirancang pada tahap sebelumnya yaitu tahap inception seperti pada Gambar 4, dilakukan perubahan pada tahap elaboration karena adanya penambahan kebutuhan sistem yaitu sebuah menu untuk memungkinkan pasien melihat riwayat pemeriksaan pribadinyasehingga pasien dapat melihat detail hasil pemeriksaan yang telah dilakukan. Usecase setelah dilakukan perubahan dapat dilihat pada Gambar 5.

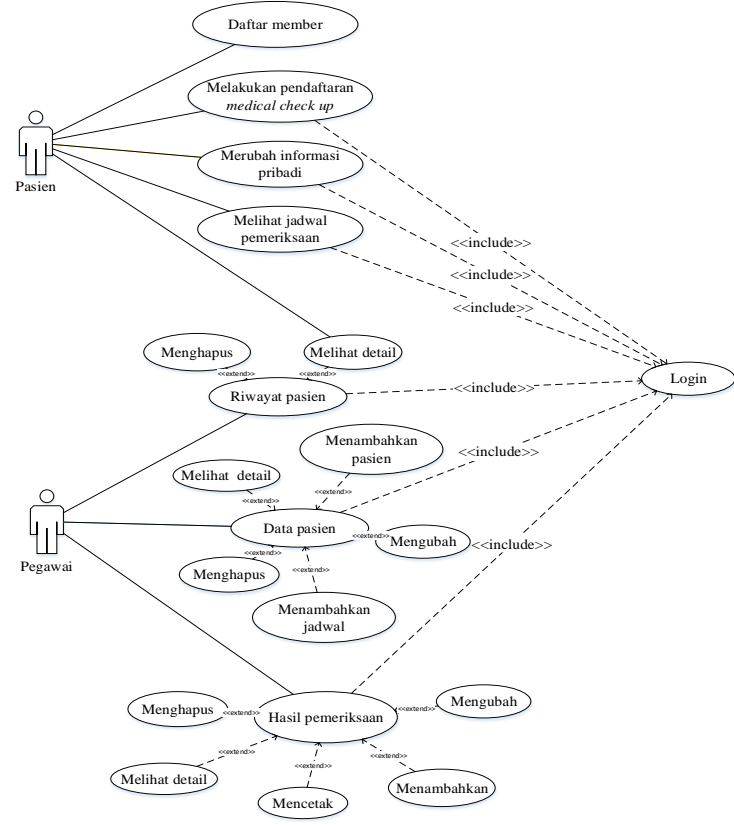

Gambar 5. Usecase diagram sistem setelah dilakukan perubahan.

2. Activity diagram

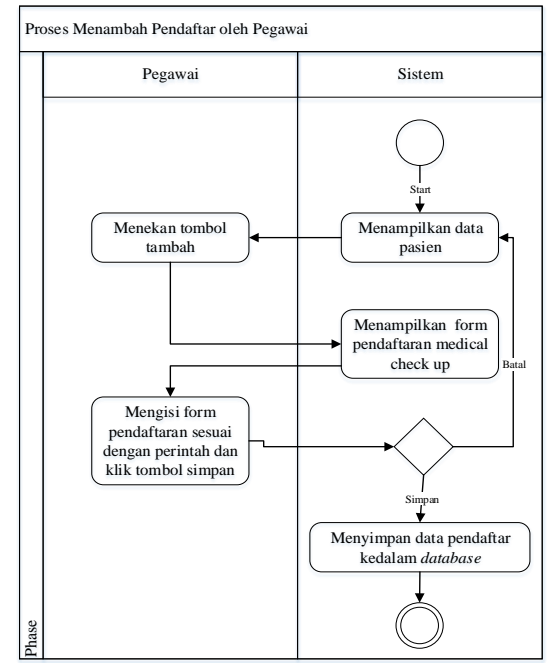

Gambar 6. Activity diagram pendafataran pasien oleh pegawai

Gambar 6 merupakan activity diagram pegawai untuk menambahkan pasien dengan mengisi form medical checkup.

3. Class diagram

Keterhubungan antar kelas yang terdapat pada sistem dapat dilihat pada Gambar 7 . Sistem yang akan dibangun menggunakan pola arsitektur Models Views Controllers (MVC), sehingga dilakukan perancangan kelas - kelas yang ada pada sistem yang terdiri dari kelas Controllers, Viewsdan Models. 


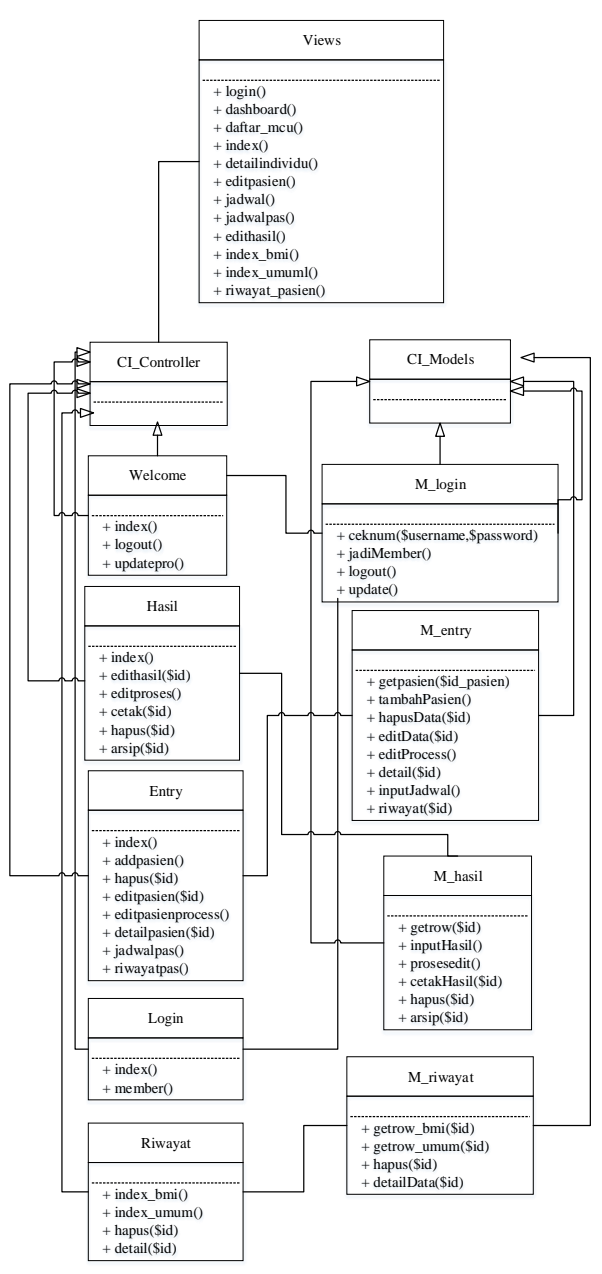

Gambar 7. Class diagram sistem

4. Sequence diagram

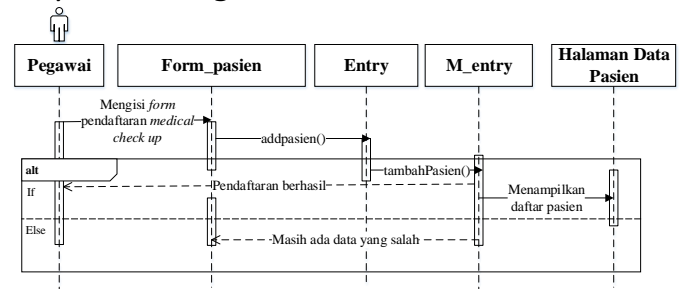

Gambar 8. Sequence diagram untuk proses penambahan pasien oleh pegawai Pada Gambar 8, proses menambahkan pasien dilakukan dengan mengisi form pasien yang disediakan, selanjutnya akan di akses fungsi addpasien() pada controllerEntry dan jika sesuai maka data tersebut akan tersimpan dalam database dengan fungsi tambahPasien() pada model M_entry.

5. Entity Relationship Diagram (ERD)

ERD sistem yang akan dibangun dapat dilihat pada Gambar 9, dimana terdapat tabel member, tabel pasien, dan tabel hasil.

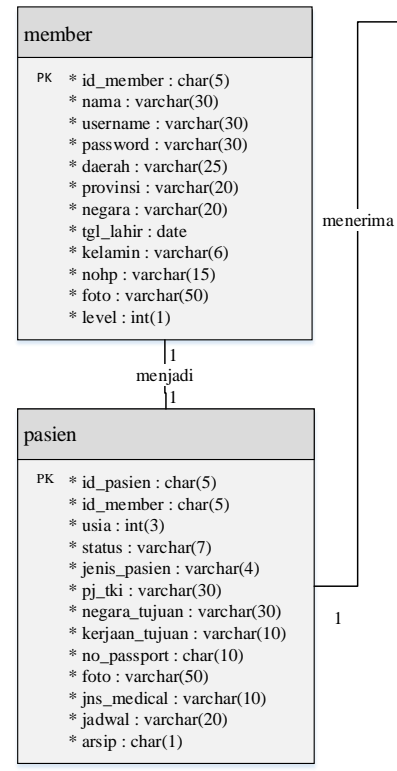

Gambar 9. ERD sistem

6. Implementation

Implementasi yang dilakukan pada tahap elaboration adalah perancangan interface sistem. Salah satu rancangan interface sistem seperti yang terlihat pada Gambar 10 yang merupakan rancangan untuk proses penambahan pasien baru yang dilakukan oleh pegawai.

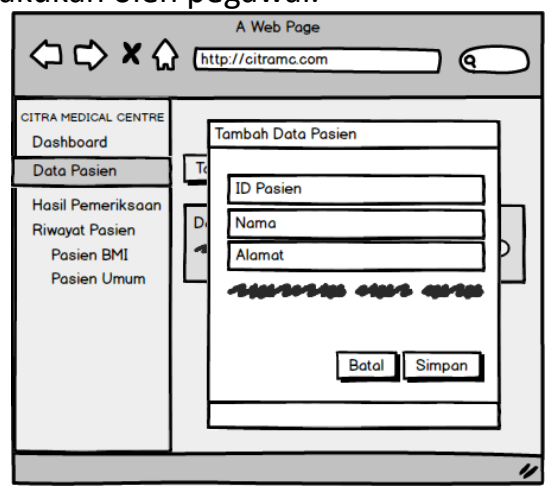

Gambar 10. Desaininterface halaman tambah pasien oleh pegawai.

7. Test

Pada tahap elaboration, pengujian dibutuhkan untuk menguji fitur yang telah dirancang apakah sudah sesuai dengan 
yang diinginkan pengguna atau belum. Pengujian dilakukan oleh 2 orang penguji yaitu pegawai dan pimpinan klinik. Proses validasi fitur dimulai dengan peneliti menampilkan rancangan interface sistem, setelah itu responden memberikan pernyataan setuju atau tidak setuju pada tabel isian yang telah disediakan. Hasil validasi dapat dilihat pada Tabel III.

TABEL III. VALIDASIFITURSISTEM

\begin{tabular}{|c|c|c|c|c|}
\hline \multirow{2}{*}{ No } & \multirow{2}{*}{$\begin{array}{c}\text { Pengg } \\
\text { una }\end{array}$} & \multirow{2}{*}{ Fitur } & \multicolumn{2}{|c|}{ Validasi } \\
\hline & & & Setuju & Tidak \\
\hline \multirow[t]{5}{*}{1} & \multirow[t]{5}{*}{ Pasien } & $\begin{array}{l}\text { Daftar } \\
\text { member }\end{array}$ & $\checkmark$ & \\
\hline & & $\begin{array}{l}\text { Melakuka } \\
\text { npendafta } \\
\text { ran } \\
\text { Medical } \\
\text { check up }\end{array}$ & $\checkmark$ & \\
\hline & & $\begin{array}{l}\text { Menguba } \\
\text { hinformas } \\
\text { ipribadi }\end{array}$ & $\checkmark$ & \\
\hline & & $\begin{array}{l}\text { Melihatja } \\
\text { dwalpeme } \\
\text { riksaan }\end{array}$ & $\checkmark$ & \\
\hline & & $\begin{array}{l}\text { Melihatri } \\
\text { wayatpem } \\
\text { eriksaan }\end{array}$ & $\checkmark$ & \\
\hline \multirow[t]{9}{*}{2} & \multirow[t]{9}{*}{ Admin } & $\begin{array}{l}\text { Melihat } \\
\text { detail } \\
\text { riwayatpa } \\
\text { sien }\end{array}$ & $\checkmark$ & \\
\hline & & $\begin{array}{l}\text { Menghap } \\
\text { usriwayat } \\
\text { pasien }\end{array}$ & $\checkmark$ & \\
\hline & & $\begin{array}{l}\text { Melihat } \\
\text { detail } \\
\text { data } \\
\text { pasien }\end{array}$ & $\checkmark$ & \\
\hline & & $\begin{array}{l}\text { Menamba } \\
\text { hkanpasie } \\
\text { nbaru }\end{array}$ & $\checkmark$ & \\
\hline & & $\begin{array}{l}\text { Menguba } \\
\mathrm{h} \text { data } \\
\text { pasien }\end{array}$ & $\checkmark$ & \\
\hline & & $\begin{array}{l}\text { Menamba } \\
\text { hkanjadw } \\
\text { alpemerik } \\
\text { saan }\end{array}$ & $\checkmark$ & \\
\hline & & $\begin{array}{l}\text { Menghap } \\
\text { us data } \\
\text { pasien }\end{array}$ & $\checkmark$ & \\
\hline & & $\begin{array}{l}\text { Melihat } \\
\text { detail } \\
\text { hasilpeme } \\
\text { riksaan }\end{array}$ & $\checkmark$ & \\
\hline & & $\begin{array}{l}\text { Menamba } \\
\text { hkanhasil }\end{array}$ & $\checkmark$ & \\
\hline
\end{tabular}

\begin{tabular}{|l|l|l|l|}
\hline & $\begin{array}{l}\text { pemeriksa } \\
\text { an }\end{array}$ & & \\
\cline { 2 - 4 } & $\begin{array}{l}\text { Mencetak } \\
\text { hasilpeme } \\
\text { riksaan }\end{array}$ & $\checkmark$ & \\
\hline & $\begin{array}{l}\text { Mengarsi } \\
\text { pkanhasil } \\
\text { pemeriksa } \\
\text { an }\end{array}$ & $\checkmark$ & \\
\hline $\begin{array}{l}\text { Menghap } \\
\text { ushasilpe } \\
\text { meriksaan }\end{array}$ & $\checkmark$ & \\
\hline
\end{tabular}

Dari pengujian yang dilakukan oleh 2 orang penguji, dapat disimpulkan bahwa rancangan interface sistem telah sesuai dengan keinginan pengguna. Maka proses dapat dilanjutkan menuju tahap constructionatau pengembangan sistem.

\section{HASILDANPEMBAHASAN}

Penerapan metode RUP pada pengembangan sistem dari keempat tahapan RUP adalah sebagai berikut.

\subsection{Tahap/nception}

Pada tahap inception dilakukan perancangan business modeling canvas, pendefinisan kebutuhan sistem, perancangan usecase diagram, dan pengujian rancangan.

\subsection{Tahap Elaboration}

Pada tahap elaboration dilakukan penambahan kebutuhan sistem dan usecase diagram, perancangan activity diagram, class diagram, sequence diagram, dan ERD, serta pengujian validasi fitur yang telah dirancang.

\subsection{Tahap Construction}

Pada tahap contruction terdapat dua proses RUP yang dilakukan yaitu implementationdan test, karena proses implementation sudah selesai pada tahap elaboration.

\subsubsection{Implemetation}

Implementasi pada tahap ini adalah pembuatan database, pengembangan sistem, dan interface sistem.

a. Database

Pada pengembangan database sistem informasi medicalcheckup Klinik Citra, terdapat 3 tabel yang digunakan yaitu tabel member, tabel pasien dan tabel hasil.

1. Tabel member 


\begin{tabular}{|c|c|c|c|c|c|c|}
\hline \multicolumn{3}{|c|}{ Browse } & Structure & \& SQL Q Search & \multicolumn{2}{|c|}{ 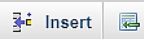 } \\
\hline & & Name & Type & Collation & es Null & Default \\
\hline$\square$ & & id_member & $\operatorname{char}(5)$ & latin1_swedish_ci & No & None \\
\hline$\square$ & & nama & varchar(30) & latin1_swedish_ci & No & None \\
\hline$\square$ & & username & varchar(30) & latin1_swedish_ci & No & None \\
\hline$\square$ & & password & varchar(30) & latin1_swedish_ci & No & None \\
\hline$\square$ & & daerah & varchar(25) & latin1_swedish_ci & No & None \\
\hline$\square$ & & provinsi & $\operatorname{varchar}(20)$ & latin1_swedish_ci & No & None \\
\hline$\square$ & & negara & $\operatorname{varchar}(20)$ & latin1_swedish_ci & No & None \\
\hline$\square$ & 8 & tgl_lahir & date & & No & None \\
\hline$\square$ & 9 & kelamin & $\operatorname{varchar}(6)$ & latin1_swedish_ci & No & None \\
\hline$\square$ & 10 & nohp & $\operatorname{varchar}(15)$ & latin1_swedish_ci & No & None \\
\hline$\square$ & 11 & foto & $\operatorname{varchar}(50)$ & latin1_swedish_ci & No & None \\
\hline$\square$ & 12 & level & $\operatorname{int}(1)$ & & No & None \\
\hline
\end{tabular}

Gambar 11. Tabel member

Pada tabel member terdapat 12 atribut seperti yang terlihat pada Gambar 11. Tabel member digunakan untuk menampung data member yang akan digunakan untuk melakukan pendaftaran medicalcheckup.

2. Tabel pasien

Pada tabel pasien terdapat 13 atribut seperti yang terlihat pada Gambar 12 . Tabel pasien ini digunakan untuk menampung data pasien yang telah melakukan pendaftaran medicalcheckup.

\begin{tabular}{|c|c|c|c|c|c|c|}
\hline & \# Name & Type & Collation & Attributes & Null & Default \\
\hline$\square$ & 1 id_pasien & char(5) & latin1_swedish_ci & & No & None \\
\hline$\square$ & 2 id_member & char(5) & latin1_swedish_ci & & No & None \\
\hline$\square$ & 3 usia & $\operatorname{int}(3)$ & & & No & None \\
\hline$\square$ & 4 status & $\operatorname{varchar}(7)$ & latin1_swedish_ci & & No & None \\
\hline$\square$ & 5 jenis_pasien & $\operatorname{varchar(4)}$ & latin1_swedish_ci & & No & None \\
\hline$\square$ & 6 pj_tki & varchar(30) & latin1_swedish_ci & & No & None \\
\hline$\square$ & 7 negara_tujuan & varchar(30) & latin1_swedish_ci & & No & None \\
\hline$\square$ & 8 kerjaan_tujuan & $\operatorname{varchar}(10)$ & latin1_swedish_ci & & No & None \\
\hline$\square$ & 9 no_passport & $\operatorname{char}(10)$ & latin1_swedish_ci & & No & None \\
\hline$\square$ & 10 foto & $\operatorname{varchar}(50)$ & latin1_swedish_ci & & No & None \\
\hline$\square$ & 11 jns_medical & varchar(10) & latin1_swedish_ci & & No & None \\
\hline$\square$ & 12 jadwal & date & & & No & None \\
\hline$\square$ & 13 arsip & $\operatorname{char}(1)$ & latin1_swedish_ci & & No & None \\
\hline
\end{tabular}

Gambar 12. Tabel pasien.

3. Tabel hasil

Pada tabel hasil terdapat 46 atribut seperti yang terlihat pada Gambar 13. Tabel hasil ini digunakan untuk menampung data hasil pemeriksaan pasien.

\begin{tabular}{|c|c|c|c|c|c|c|}
\hline & $\#$ & Name & Type & Attributes & Null & Default \\
\hline D & 1 & id_hasil & $\operatorname{int}(5)$ & & No & None \\
\hline ○ & 2 & id_pasien & $\operatorname{char}(5)$ & latin1_swedish_ci & No & None \\
\hline$\bullet$ & 3 & tinggi & $\operatorname{int}(3)$ & & No & None \\
\hline$\square$ & 4 & berat & $\operatorname{int}(3)$ & & No & None \\
\hline$\square$ & 5 & m_kanan & $\operatorname{char}(5)$ & latin1_swedish_ci & No & None \\
\hline$\square$ & 6 & m_kiri & char(5) & latin1_swedish_ci & No & None \\
\hline$\square$ & 7 & td_atas & $\operatorname{int}(3)$ & & No & None \\
\hline$\square$ & 8 & td_bawah & $\operatorname{int}(3)$ & & No & None \\
\hline$\square$ & 9 & nadi & $\operatorname{int}(3)$ & & No & None \\
\hline D & 10 & gol & $\operatorname{varchar}(3)$ & latin1_swedish_ci & No & None \\
\hline$\square$ & 11 & suhu & $\operatorname{int}(3)$ & & No & None \\
\hline$\square$ & 12 & rontgen & $\operatorname{varchar}(8)$ & latin1_swedish_ci & No & None \\
\hline$\square$ & 13 & hasil_fisik & $\operatorname{varchar}(7)$ & latin1_swedish_ci & No & None \\
\hline$\square$ & 14 & bilirub & $\operatorname{varchar}(8)$ & latin1_swedish_ci & No & None \\
\hline$\square$ & 15 & reduction & $\operatorname{varchar}(8)$ & latin1_swedish_ci & No & None \\
\hline$\square$ & 16 & protein & $\operatorname{varchar}(8)$ & latin1_swedish_ci & No & None \\
\hline$\square$ & 17 & color & $\operatorname{varchar}(17)$ & latin1_swedish_ci & No & None \\
\hline$\square$ & 18 & ph & $\operatorname{varchar}(8)$ & latin1_swedish_ci & No & None \\
\hline$\square$ & 19 & bj & $\operatorname{varchar}(8)$ & latin1_swedish_ci & No & None \\
\hline$\square$ & 20 & $w b c$ & $\operatorname{varchar}(8)$ & latin1_swedish_ci & No & None \\
\hline$\square$ & 21 & hb & $\operatorname{varchar}(8)$ & latin1_swedish_ci & No & None \\
\hline$\square$ & 22 & glukosa & $\operatorname{varchar}(8)$ & latin1_swedish_ci & No & None \\
\hline$\square$ & 23 & ureum & $\operatorname{varchar}(8)$ & latin1_swedish_ci & No & None \\
\hline$\square$ & 24 & creatinin & $\operatorname{varchar}(8)$ & latin1_swedish_ci & No & None \\
\hline$\square^{2}$ & 25 & sgot & $\operatorname{varchar}(8)$ & latin1_swedish_ci & No & None \\
\hline$\square^{2}$ & 26 & sgpt & $\operatorname{varchar}(8)$ & latin1_swedish_ci & No & None \\
\hline$\square 2$ & 27 & alkali & $\operatorname{varchar}(8)$ & latin1_swedish_ci & No & None \\
\hline$\square 2$ & 28 & albumin & $\operatorname{varchar}(8)$ & latin1_swedish_ci & No & None \\
\hline$\square$ & 29 & vdrl & $\operatorname{varchar}(8)$ & latin1_swedish_ci & No & None \\
\hline$\square$ & 30 & tpha & $\operatorname{varchar}(8)$ & latin1_swedish_ci & No & None \\
\hline$\square$ & 31 & hbs_ag & $\operatorname{varchar}(8)$ & latin1_swedish_ci & No & None \\
\hline$\square$ & 32 & hiv & $\operatorname{varchar}(8)$ & latin1_swedish_ci & No & None \\
\hline$\square$ & 33 & hev & $\operatorname{varchar}(8)$ & latin1_swedish_ci & No & None \\
\hline$\square$ & 34 & canabis & $\operatorname{varchar}(8)$ & latin1_swedish_ci & No & None \\
\hline$\square$ & 35 & opiates & $\operatorname{varchar}(8)$ & latin1_swedish_ci & No & None \\
\hline$\square$ & 36 & amphetamin & $\operatorname{varchar}(8)$ & latin1_swedish_ci & No & None \\
\hline$\square$ & 37 & cholesterol & $\operatorname{varchar}(8)$ & latin1_swedish_ci & No & None \\
\hline$\square$ & 38 & feses & $\operatorname{varchar}(8)$ & latin1_swedish_ci & No & None \\
\hline$\square$ & 39 & hamil & $\operatorname{varchar}(3)$ & latin1_swedish_ci & No & None \\
\hline$\square$ & 40 & hasil_lab & $\operatorname{varchar}(7)$ & latin1_swedish_ci & No & None \\
\hline$\square$ & 41 & frek_kanan & $\operatorname{varchar}(8)$ & latin1_swedish_ci & No & None \\
\hline$\square$ & 42 & frek_kiri & $\operatorname{varchar}(8)$ & latin1_swedish_ci & No & None \\
\hline$\square$ & 43 & hasil_audio & $\operatorname{varchar}(7)$ & latin1_swedish_ci & No & None \\
\hline$\square$ & 44 & status_akhir & $\operatorname{varchar}(7)$ & latin1_swedish_ci & No & None \\
\hline$\square$ & 45 & tgl_selesai & date & & No & None \\
\hline$\square$ & 46 & arsip & $\operatorname{char}(1)$ & latin1_swedish_ci & Yes & NULL \\
\hline
\end{tabular}

Gambar 13. Tabel hasil

b. Project

Pengembangan sistem dengan frameworkcodeigniter menggunakan konsep MVC yaitu Models, Views dan Controllers. Models berisi fungsi yang dapat digunakan untuk mengelola database, Views untuk mengatur tampilan, dan Controllers berisi fungsi untuk memproses data dan merupakan bagian yang berfungsi sebagai penghubung antara Models dan Views.

c. Interface

Halaman log in pada Gambar 14 digunakan untuk dapat masuk ke sistem dengan memasukkan username dan password jika sudah memiliki akun, Sedangkan jika belum maka harus melakukan pendaftaran untuk 
menjadi member dengan memilih tombol Signup. Halaman $\log$ in ini bisa digunakan bersama oleh pegawai maupun pasien.

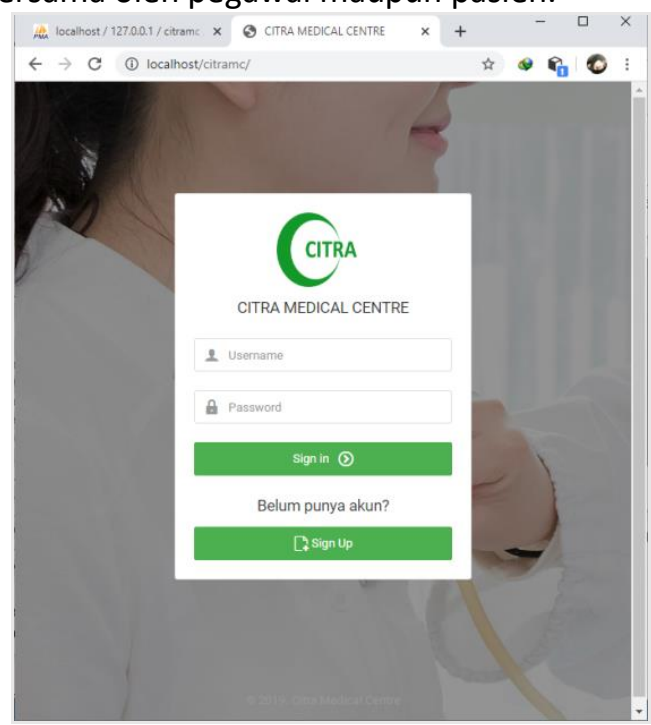

Gambar 14. Halaman awal sistem

d. Test

Pada tahap construction dilakukan pengujian untuk fitur sistem yang telah dibangun dan kesesuaian sistem dengan kebutuhan pengguna. Pengujian dilakukan dengan menggunakan blackbox testing untuk pengujian functional suitability.

1. Functional Completeness

Pada pengujian functional completeness terdapat 20 fitur yang di uji untuk admin dan juga pasien yaitu sepeti yang terlihat Tabel IV.

TABEL IV. PEnguJIANFUngsI COMPLETENESS

\begin{tabular}{|c|c|c|c|c|}
\hline \multirow[t]{2}{*}{ No } & \multirow[t]{2}{*}{ Fungsi } & \multirow{2}{*}{$\begin{array}{l}\text { Hasil yang } \\
\text { diharapkan }\end{array}$} & \multicolumn{2}{|c|}{$\begin{array}{c}\text { Hasil } \\
\text { pengujian }\end{array}$} \\
\hline & & & Sesuai & Tidak \\
\hline \multicolumn{5}{|c|}{ Admin } \\
\hline 1 & $\begin{array}{l}\text { Log in } \\
\text { sebagai } \\
\text { admin }\end{array}$ & $\begin{array}{l}\text { Fungsi log in } \\
\text { sebagai admin } \\
\text { sudah } \\
\text { berjalan } \\
\text { dengan benar }\end{array}$ & $\checkmark$ & \\
\hline 2 & $\begin{array}{l}\text { Menam } \\
\text { bahkan } \\
\text { data } \\
\text { pasien }\end{array}$ & $\begin{array}{l}\text { Fungsi } \\
\text { tambah } \\
\text { pasien sudah } \\
\text { berjalan } \\
\text { dengan benar }\end{array}$ & $\checkmark$ & \\
\hline 3 & $\begin{array}{l}\text { Melihat } \\
\text { detail } \\
\text { data } \\
\text { pasien }\end{array}$ & $\begin{array}{l}\text { Fungsi lihat } \\
\text { detail data } \\
\text { pasien sudah } \\
\text { berjalan } \\
\text { dengan benar }\end{array}$ & $\checkmark$ & \\
\hline 4 & $\begin{array}{l}\text { Mengub } \\
\text { ah data } \\
\text { pasien }\end{array}$ & $\begin{array}{lr}\text { Fungsi } & \text { ubah } \\
\text { data } & \text { pasien } \\
\text { sudah } & \end{array}$ & $\checkmark$ & \\
\hline
\end{tabular}

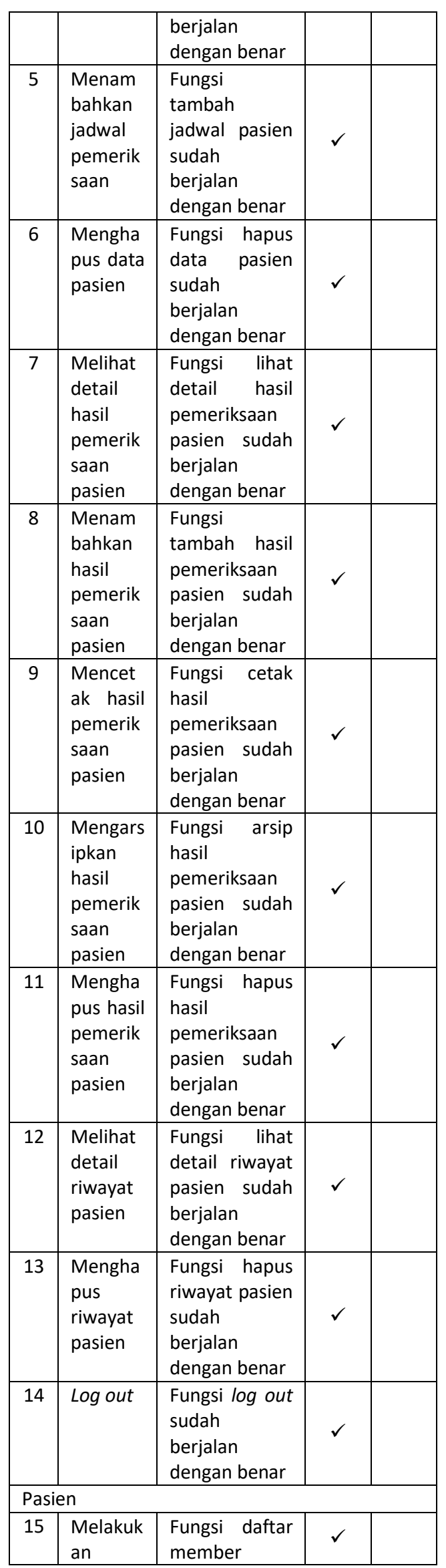




\begin{tabular}{|c|c|c|c|}
\hline & $\begin{array}{l}\text { pendaft } \\
\text { aran } \\
\text { sebagai } \\
\text { member }\end{array}$ & $\begin{array}{l}\text { sudah } \\
\text { berjalan } \\
\text { dengan benar }\end{array}$ & \\
\hline 16 & $\begin{array}{l}\text { Log } \\
\text { insebaga } \\
\text { i pasien }\end{array}$ & $\begin{array}{l}\text { Fungsi log in } \\
\text { sebagai pasien } \\
\text { sudah } \\
\text { berjalan } \\
\text { dengan benar }\end{array}$ & $\checkmark$ \\
\hline 17 & $\begin{array}{l}\text { Melakuk } \\
\text { an } \\
\text { pendaft } \\
\text { aran } \\
\text { medicalc } \\
\text { heckup }\end{array}$ & $\begin{array}{l}\text { Fungsi daftar } \\
\text { medicalcheck } \\
\text { up sudah } \\
\text { berjalan } \\
\text { dengan benar }\end{array}$ & $\checkmark$ \\
\hline 18 & $\begin{array}{l}\text { Melihat } \\
\text { jadwal } \\
\text { pemerik } \\
\text { saan } \\
\text { pribadi }\end{array}$ & $\begin{array}{l}\text { Fungsi lihat } \\
\text { jadwal } \\
\text { pemeriksaan } \\
\text { pribadi sudah } \\
\text { berjalan } \\
\text { dengan benar }\end{array}$ & $\checkmark$ \\
\hline 19 & $\begin{array}{l}\text { Melihat } \\
\text { riwayat } \\
\text { pemerik } \\
\text { saan } \\
\text { pribadi }\end{array}$ & $\begin{array}{l}\text { Fungsi lihat } \\
\text { riwayat } \\
\text { pemeriksaan } \\
\text { pribadi sudah } \\
\text { berjalan } \\
\text { dengan benar }\end{array}$ & $\checkmark$ \\
\hline 20 & $\begin{array}{l}\text { Mengub } \\
\text { ah data } \\
\text { pribadi }\end{array}$ & $\begin{array}{l}\text { Fungsi ubah } \\
\text { data pribadi } \\
\text { sudah } \\
\text { berjalan } \\
\text { dengan benar }\end{array}$ & $\checkmark$ \\
\hline
\end{tabular}

Berdasarkan pengujian dengan Tabel IV yang dilakukan oleh 2 orang pengguna diperoleh hasil seperti pada Tabel V.

TABEL V. HASIL PENGUJIAN FUNGSI COMPLETENESS

\begin{tabular}{|c|c|c|}
\hline Nomor Fungsi & Sesuai & Tidak \\
\hline 1 & 2 & 0 \\
\hline 2 & 2 & 0 \\
\hline 3 & 2 & 0 \\
\hline 4 & 2 & 0 \\
\hline 5 & 2 & 0 \\
\hline 6 & 2 & 0 \\
\hline 7 & 2 & 0 \\
\hline 8 & 2 & 0 \\
\hline 9 & 2 & 0 \\
\hline 10 & 2 & 0 \\
\hline 11 & 2 & 0 \\
\hline 12 & 2 & 0 \\
\hline 13 & 2 & 0 \\
\hline 14 & 2 & 0 \\
\hline 15 & 2 & 0 \\
\hline 16 & 2 & 0 \\
\hline 17 & 2 & 0 \\
\hline 18 & 2 & 0 \\
\hline 19 & 2 & 0 \\
\hline
\end{tabular}

\begin{tabular}{|c|c|c|}
\hline 20 & 2 & 0 \\
\hline Total & $\mathbf{4 0}$ & $\mathbf{0}$ \\
\hline
\end{tabular}

$\mathrm{P}=$ Jumlah pernyataan $\mathrm{x}$ jumlah penguji $=$ 40

$\mathrm{I}=$ Jumlah nilai $\mathrm{x}$ jumlah penguji $=40$

Sehingga $X=\frac{40}{40}=1$

Pada pengujian yang diperoleh hasil sama dengan 1, jadi dapat disimpulkan bahwa semua fitur sudah berfungsi dengan baik

2. Functional Correctness

Pada pengujian functional correctness terdapat 5 fitur yang di uji untuk admin dan juga pasien yaitu sepeti yang terlihat Tabel VI.

TABEL VI. PENGUJIANFUNGSI CORRECTNESS.

\begin{tabular}{|c|c|c|c|c|}
\hline \multirow[t]{2}{*}{ No } & \multirow[t]{2}{*}{ Fungsi } & \multirow{2}{*}{$\begin{array}{l}\text { Hasil yang } \\
\text { diharapkan }\end{array}$} & \multicolumn{2}{|c|}{$\begin{array}{c}\text { Hasil } \\
\text { pengujian }\end{array}$} \\
\hline & & & Sesuai & Tidak \\
\hline \multicolumn{5}{|c|}{ Umum } \\
\hline 1 & $\begin{array}{l}\text { Identifik } \\
\text { asi } \\
\text { usernam } \\
e \quad \text { dan } \\
\text { passwor } \\
d\end{array}$ & $\begin{array}{l}\text { Proses log in } \\
\text { ke sistem } \\
\text { sesuai dengan } \\
\text { jenis } \\
\text { usersudah } \\
\text { berjalan } \\
\text { degan benar }\end{array}$ & $\checkmark$ & \\
\hline 2 & $\begin{array}{l}\text { Perhitun } \\
\text { gan } \\
\text { jumlah } \\
\text { data } \\
\text { pasien } \\
\text { pada } \\
\text { dahboar } \\
d\end{array}$ & $\begin{array}{l}\text { Proses } \\
\text { menampilkan } \\
\text { grafik jumlah } \\
\text { data pasien } \\
\text { sesuai dengan } \\
\text { jenis kelamin } \\
\text { dan jenis } \\
\text { pasien pada } \\
\text { dahboard } \\
\text { sistem sudah } \\
\text { berjalan } \\
\text { dengan benar }\end{array}$ & $\checkmark$ & \\
\hline \multicolumn{5}{|c|}{ Admin } \\
\hline 3 & $\begin{array}{l}\text { Menam } \\
\text { pilkan } \\
\text { data } \\
\text { pasien } \\
\text { berdasa } \\
\text { rkan } \\
\text { pencaria } \\
\mathrm{n}\end{array}$ & $\begin{array}{l}\text { Proses } \\
\text { pencarian } \\
\text { pada data } \\
\text { pasien } \\
\text { berdasarkan } \\
\text { kata kunci } \\
\text { tertentu } \\
\text { sudah } \\
\text { berjalan } \\
\text { dengan benar } \\
\end{array}$ & $\checkmark$ & \\
\hline 4 & $\begin{array}{l}\text { Menam } \\
\text { pilkan } \\
\text { data } \\
\text { hasil } \\
\text { pemerik } \\
\text { saan } \\
\text { berdasa } \\
\text { rkan }\end{array}$ & $\begin{array}{l}\text { Proses } \\
\text { pencarian } \\
\text { pada hasil } \\
\text { pemeriksaan } \\
\text { pasien } \\
\text { berdasarkan } \\
\text { kata kunci } \\
\text { tertentu }\end{array}$ & $\checkmark$ & \\
\hline
\end{tabular}




\begin{tabular}{|c|l|l|l|l|}
\hline & $\begin{array}{l}\text { pencaria } \\
\mathrm{n}\end{array}$ & $\begin{array}{l}\text { sudah } \\
\text { berjalan } \\
\text { dengan benar }\end{array}$ & & \\
\hline 5 & $\begin{array}{l}\text { Menam } \\
\text { pilkan } \\
\text { riwayat } \\
\text { pasien } \\
\text { berdasa } \\
\text { rkan } \\
\text { pencaria } \\
\mathrm{n}\end{array}$ & $\begin{array}{l}\text { Proses } \\
\text { pencarian } \\
\text { pada riwayat } \\
\text { pasien } \\
\text { berdasarkan } \\
\text { kata kunci } \\
\text { tertentu } \\
\text { sudah } \\
\text { berjalan } \\
\text { dengan benar }\end{array}$ & $\checkmark$ & \\
\end{tabular}

Berdasarkan pengujian dari Tabel VI diperoleh hasil seperti pada Tabel VII.

TABEL VII. HASILPENGUJIANFUNGSI CORRECTNESS.

\begin{tabular}{|c|c|c|}
\hline Nomor Fungsi & Sesuai & Tidak \\
\hline 1 & 2 & 0 \\
\hline 2 & 2 & 0 \\
\hline 3 & 2 & 0 \\
\hline 4 & 2 & 0 \\
\hline 5 & 2 & 0 \\
\hline Total & 10 & 0 \\
\hline
\end{tabular}

$\mathrm{P}=$ Jumlah pernyataan $\mathrm{x}$ jumlah penguji $=$ 10

$\mathrm{I}=$ Jumlah nilai $\mathrm{x}$ jumlah penguji $=10$

Sehingga $X=\frac{10}{10}=1$

Pada pengujian yang dilakukan diperoleh hasil sama dengan 1 , jadi dapat disimpulkan bahwa semua fitur sudah berjalan dengan baik

3. FunctionalAppropriateness

Pada

pengujian

functionalappropriatenessterdapat 1 fitur yang di uji untuk admin yaitu seperti yang terlihat pada Tabel VIII.

TABEL VIII. PenguJianfungsiappropriaten

\begin{tabular}{|l|l|l|c|c|}
\hline \multirow{2}{*}{ No } & Fungsi & \multicolumn{1}{c|}{$\begin{array}{c}\text { Hasil yang } \\
\text { diharapkan }\end{array}$} & \multicolumn{2}{|c|}{$\begin{array}{c}\text { Hasil } \\
\text { pengujian }\end{array}$} \\
\cline { 4 - 5 } & & Sesuai & Tidak \\
\hline \multicolumn{3}{|c|}{ Admin } & \\
\hline 1 & $\begin{array}{l}\text { Menc } \\
\text { etak } \\
\text { hasil } \\
\text { pemer } \\
\text { iksaan } \\
\text { pasien }\end{array}$ & $\begin{array}{l}\text { Fungsi } \\
\text { mencetak } \\
\text { hasil } \\
\text { pemeriksaan } \\
\text { pasien yang } \\
\text { bersangkutan } \\
\text { menghasilkan } \\
\text { output yang } \\
\text { benar }\end{array}$ & $\checkmark$ & \\
\hline
\end{tabular}

Berdasarkan pengujian dengan Tabel VIII yang dilakukan oleh 2 orang pengguna diperoleh hasil seperti pada Tabel IX.

TABEL IX. HASILPENGUJIANFUNGSIAPPROPRIA

\begin{tabular}{|c|c|c|}
\hline TENESS \\
\hline 1 & 2 & 0 \\
\hline Total & $\mathbf{2}$ & $\mathbf{0}$ \\
\hline
\end{tabular}

$\mathrm{P}=$ Jumlah pernyataan $\mathrm{x}$ jumlah penguji $=$ 2

$\mathrm{I}=$ Jumlah nilai $\mathrm{x}$ jumlah penguji $=2$

Sehingga $X=\frac{2}{2}=1$

Pada pengujian yang dilakukan terhadap ketiga functional sistem diperoleh hasil sama dengan 1, jadi dapat disimpulkan bahwa semua fitur sistem sudah berjalan dengan baik, sehingga proses dapat dilanjutkan menuju tahap transition.

\subsection{Tahap Transition}

Tahap transition adalah tahap selanjutnya dari tahap constuction. Pada tahap ini akan dilakukan pengujian usability sistem untuk mengetahui kesesuaian sistem dengan kebutuhan pengguna. Proses pengujian dilakukan oleh dua pihak, yaitu dari pihak klinik sebagai admin, dan dari pihak masyarakat umum sebagai pasien.

\subsubsection{Admin}

Pengujian untuk pihak klinik dilakukan oleh 2 orang yaitu pegawai dan pimpinan klinik. Pengujian menggunakan kuesioner dengan 21 butir pernyataanyang terbagi menjadi 4 kriteriayaitu usefulness, ease of use, ease of learningdansatisfaction[5].

Dari pengujian yang dilakukan oleh 2 orang pengguna diperoleh hasil seperti yang terlihat pada Gambar 15.

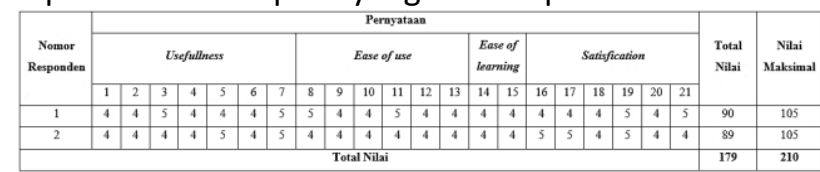

Gambar 15. Hasil pengujian usability sistem oleh pihak klinik.

Berdasarkan hasil pengujian pada Gambar 15, nilai yang diperoleh sebesar 179. Hasil pengujian usability dihitung menggunakan rumus sebagai berikut.

$$
\text { P Skor }=\quad x 100 \%=85,23 \%
$$

Dari hasil perhitungan diperoleh persentase pengujian usability sebesar 85,23\%, sehingga sistem informasi medical checkup dapat dinyatakan "Sangat Layak" dan memenuhi standar usability. 


\subsubsection{Pasien}

Pengujian dari pihak pasien dilakukan oleh 30 orang yang diambil secara acak dari berbagai bidang pekerjaan. Pengujian menggunakan kuesioner dengan 8 butir pernyataan yang terbagi menjadi 4 kriteria yaitu usefulness, ease of use, ease of learning dan satisfaction[5].

Dari pengujian yang dilakukan oleh 30 orang pengguna diperoleh hasil seperti yang terlihat pada Tabel $\mathrm{X}$.

TABEL $X$. HASILPENGUJIANOLEHPASIEN

\begin{tabular}{|c|c|c|c|c|c|c|c|c|c|c|}
\hline \multirow{3}{*}{ No } & \multicolumn{8}{|c|}{ Pernyataan } & \multirow{3}{*}{$\begin{array}{l}\text { Total } \\
\text { Nilai }\end{array}$} & \multirow{3}{*}{$\begin{array}{c}\text { Nilai } \\
\text { Maksimal }\end{array}$} \\
\hline & \multirow{2}{*}{$\begin{array}{c}\begin{array}{c}\text { Usef } \\
\text { ulln } \\
\text { ess }\end{array} \\
1\end{array}$} & \multicolumn{2}{|c|}{ Ease of use } & \multicolumn{2}{|c|}{$\begin{array}{l}\text { Ease of } \\
\text { learning }\end{array}$} & \multicolumn{3}{|c|}{ Satisfaction } & & \\
\hline & & 2 & 3 & 4 & 5 & 6 & 7 & 8 & & \\
\hline 1 & 4 & 5 & 4 & 4 & 4 & 5 & 5 & 4 & 35 & 40 \\
\hline 2 & 4 & 4 & 5 & 5 & 4 & 4 & 4 & 5 & 35 & 40 \\
\hline 3 & 5 & 4 & 4 & 4 & 4 & 5 & 5 & 4 & 35 & 40 \\
\hline 4 & 5 & 4 & 4 & 5 & 5 & 4 & 5 & 5 & 37 & 40 \\
\hline 5 & 4 & 4 & 4 & 3 & 4 & 4 & 5 & 4 & 32 & 40 \\
\hline 6 & 4 & 4 & 4 & 5 & 4 & 5 & 5 & 4 & 35 & 40 \\
\hline 7 & 4 & 4 & 4 & 5 & 4 & 5 & 5 & 5 & 36 & 40 \\
\hline 8 & 4 & 4 & 4 & 4 & 3 & 5 & 5 & 5 & 34 & 40 \\
\hline 9 & 4 & 4 & 5 & 4 & 4 & 4 & 5 & 5 & 35 & 40 \\
\hline 10 & 4 & 4 & 4 & 4 & 4 & 4 & 4 & 4 & 32 & 40 \\
\hline 11 & 5 & 4 & 4 & 4 & 4 & 5 & 5 & 5 & 36 & 40 \\
\hline 12 & 4 & 4 & 4 & 4 & 4 & 4 & 5 & 4 & 33 & 40 \\
\hline 13 & 5 & 4 & 4 & 5 & 4 & 5 & 5 & 4 & 36 & 40 \\
\hline 14 & 4 & 4 & 5 & 4 & 4 & 4 & 4 & 5 & 34 & 40 \\
\hline 15 & 4 & 4 & 5 & 5 & 4 & 4 & 5 & 5 & 36 & 40 \\
\hline 16 & 5 & 4 & 4 & 4 & 5 & 4 & 5 & 4 & 35 & 40 \\
\hline 17 & 4 & 4 & 4 & 5 & 5 & 4 & 5 & 4 & 35 & 40 \\
\hline 18 & 4 & 4 & 5 & 4 & 4 & 4 & 5 & 4 & 34 & 40 \\
\hline 19 & 4 & 4 & 4 & 5 & 5 & 4 & 5 & 4 & 35 & 40 \\
\hline 20 & 4 & 4 & 4 & 4 & 4 & 5 & 5 & 5 & 35 & 40 \\
\hline 21 & 4 & 4 & 4 & 4 & 4 & 5 & 5 & 4 & 34 & 40 \\
\hline 22 & 5 & 4 & 4 & 4 & 4 & 4 & 5 & 5 & 35 & 40 \\
\hline 23 & 4 & 4 & 4 & 5 & 4 & 4 & 5 & 4 & 34 & 40 \\
\hline 24 & 5 & 4 & 4 & 4 & 4 & 4 & 4 & 4 & 33 & 40 \\
\hline 25 & 5 & 4 & 4 & 4 & 4 & 5 & 5 & 5 & 36 & 40 \\
\hline 26 & 4 & 4 & 4 & 5 & 4 & 5 & 5 & 4 & 35 & 40 \\
\hline 27 & 4 & 4 & 4 & 4 & 5 & 5 & 5 & 4 & 35 & 40 \\
\hline 28 & 4 & 4 & 5 & 5 & 4 & 5 & 4 & 4 & 35 & 40 \\
\hline 29 & 5 & 4 & 4 & 4 & 5 & 4 & 5 & 4 & 35 & 40 \\
\hline 30 & 4 & 4 & 4 & 4 & 3 & 4 & 5 & 4 & 32 & 40 \\
\hline & & & Tot & lilai & & & & & 1039 & 1200 \\
\hline
\end{tabular}

Berdasarkan hasil pengujian pada Tabel $\mathrm{X}$, dapat diperoleh total nilai sebesar 1039. Hasil pengujian usability dapat diperoleh dengan menggunakan rumus sebagai berikut.

$$
\text { P Skor }=\frac{1}{1} \times 100 \%=87 \%
$$

Persentase pengujian usability diperoleh sebesar $87 \%$, sehingga dapat disimpulkan bahwa sistem informasi medical checkup memenuhi standar usability dan dinyatakan "Sangat Layak".

\section{KESIMPULAN}

Berdasarkan analisis dan pembahasan, dapat diambil kesimpulan sebagai berikut:

1. Pengujian RUP dilakukan pada setiap tahapan. Pada tahap inception dilakukan pengujian untuk validasi kebutuhan dan usecasediagram sistem yang dirancang. Tahap elaboration dilakukan pengujian untuk validasi fitur sistem. Untuk tahap construction dilakukan pengujian suitability dengan menggunakan blackbox testing, dan untuk tahap transition dilakukan pengujian usability sistem dengan menggunakan kuesioner.

2. Ketika terdapat kebutuhan sistem pada tahap inception yang masih perlu dilakukan perubahan atau penambahan, maka proses perubahannya bisa dilakukan pada tahap awal elaboration.

3. Pengujian terhadap sistem dilakukan dengan menggunakan blackbox testing dan kuesioner. Dari blackbox testing untuk pengujian fitur sistem diperoleh hasil sebesar 1 yang artinya bahwa semua fitur sistem sudah berjalan dengan benar. Pada pengujian usability diperoleh hasil sebesar $86,12 \%$ dan jika interpretasikan menjadi "Sangat Layak", sehingga metode RUP merupakan metode yang baik untuk pengembangan sistem.

\section{DAfTAR Pustaka}

[1] P. Kroll and P. Kruchten, The Rational Unified Process Made Easy. 2003.

[2] S. A. Muhamad, "Implementasi dan Pengembangan Aplikasi Kerjasama Kesehatan Medical Check Up pada Rumah Sakit Citra Medika Cibitung-BekasiJawa Barat," Universitas Islam Negeri Syarif Hidayatullah Jakarta, 2010.

[3] "Pantau PJTKI - Daftar Tempat Pemeriksaan Kesehatan (Medical Check Up) untuk BMI." [Online].

Available:http://pantaupjtki.buruhmigran.or.id/ind ex.php/read/daftar-tempat-pemeriksaankesehatan-(medical-check-up)-untuk-bmi.

[4] Beny, "Sistem Informasi Pendistribusian Suku Cadang Industri pada CV. Oilfindo Menggunakan Metode Rational Unified Process," Sekolah Tinggi Manajemen Informatika dan Komputer Palcomtech, 2019.

[5] A. A. D. I. Nugroho, "Analisis dan Pengembangan Sistem Ujian Akhir Semester Berbasis Komputer di SMK Negeri 1 Magelang," Universitas Negeri Yogyakarta, 2018.

[6] S. Young, "Penerapan Metode SDLC RUP (Rational Unified Proses) dalam Pembuatan Sistem Informasi E-kos Berbasis Web pada Kota Malang," Universitas Muhammadiyah Malang, 2018. 
[7] M. Zaminkar and M. R. Reshadinezhad, "A Comparison Between Two Software Engineering Processes, RUP And Waterfall Models," Int. J. Eng. Res. Technol., vol. 2, no. 7, pp. 1348-1352, 2013.

[8] A. Alshamrani and A. Bahattab, "A Comparison Between Three SDLC Models Waterfall Model, Spiral Model, and Incremental/Iterative Model," IJCSI Int. J. Comput. Sci. Issues, vol. 12, no. 1, pp. 106-111, 2015.
[9] F. Mubarok, H. Harliana, and I. Hadijah, “Perbandingan Antara Metode RUP dan Prototype Dalam Aplikasi Penerimaan Siswa Baru Berbasis Web," Creat. Inf. Technol. J., vol. 2, no. 2, p. 114, 2015.

[10] T. F. Alimuddin Yasin danMZ. Yumarlin, "Analisis Kebutuhan Sistem Informasi di LPK RJ-COMP Yogyakarta," no. January 2015, pp. 111-116, 2017. 